\title{
PROCESS MODEL OF IMPLEMENTATION OF GOOD PHARMACY PRACTICE IN THE ACTIVITY OF PHARMACIES OF UKRAINE
}

\author{
Candidate of pharmaceutical sciences, Associate professor Liliia Hala \\ Ukraine, Kyiv, Bogomolets National Medical University, \\ Department of Organization and Economics of Pharmacy
}

DOI: https://doi.org/10.31435/rsglobal_ws/31102019/6722

\section{ARTICLE INFO}

Received: 20 August 2019

Accepted: 15 October 2019

Published: 31 October 2019

\section{KEYWORDS}

pharmacy,

Good Pharmacy Practice,

standard operating procedure.

\begin{abstract}
Taking into account the recommendations of the FIP/WHO joint guidelines for GPP "Good pharmacy practice: standards for quality of pharmacy services", the global experience of the pharmacy and legal regulation of pharmaceutical activities in Ukraine we offered the Guidance of Good Pharmacy Practice (GPP), which focused on content, functional and role-based approach to the development of national pharmacy practice standards, by the terms of cooperation of public professional, scientific and educational organizations. We consider the national standard of GPP as an interconnected groups of tasks aimed at ensuring the performance of individual roles and functions of pharmacy specialists. The proposed project structure of the national standard of GPP complies with the generally accepted normative document construction, requirements for stage properties (standard name, subject of regulation, date of adoption) and structure (introductory part, sections, annexes). The Guidance of GPP also establishes the procedure for development of standard operating procedure (SOP) for effective use in practice with the peculiarities of each pharmacy. As follows, based on the materials, the process model of GPP implementation in pharmacies of Ukraine was proposed and the expediency of developing its components, namely the Guidance of GPP, national standards of GPP and SOPs was provided.
\end{abstract}

Citation: Liliia Hala. (2019) Process Model of Implementation of Good Pharmacy Practice in the Activity of Pharmacies of Ukraine. World Science. 10(50), Vol.1. doi: 10.31435/rsglobal ws/31102019/6722

Copyright: (C) 2019 Liliia Hala. This is an open-access article distributed under the terms of the Creative Commons Attribution License (CC BY). The use, distribution or reproduction in other forums is permitted, provided the original author(s) or licensor are credited and that the original publication in this journal is cited, in accordance with accepted academic practice. No use, distribution or reproduction is permitted which does not comply with these terms.

Introduction. Today in Ukraine the important question is the development and implementation Guidance of Good Pharmacy Practice (Good Pharmacy Practice, GPP) to improve the quality of pharmaceutical providing of the population, as required by the Concept of Pharmaceutical Sector Development of the Health Care Industry of Ukraine for 2011-2020 years and the State Strategy for the Implementation of the State policies for providing the population with medicines for the period up to 2025 year. In 2011, the International Pharmaceutical Federation (FIP) and the World Health Organization (WHO) published updated joint guidelines "Good pharmacy practice: standards for quality of pharmacy services" (then - FIP/WHO guidelines for GPP). Considering to the differences in pharmaceutical practices in different countries, WHO and the FIP emphasize that FIP/WHO guidelines for GPP is intended for use by national professional pharmaceutical associations, authorities and other authorities responsible for drafting relevant documents in their countries. As the FIP/WHO guidelines for GPP is a common base of rules and requirements, without a comprehensive description of work aspects of pharmacy, national GPP standards should be developed taking into account the regulatory legal framework for pharmaceutical activities and the particularities of domestic pharmacy practice. The FIP/WHO guidelines for GPP should be seen not as an obligatory document, but as a guidance to the 
development of national standards in order to achieve the proper level of implementation by pharmacy specialists of the specific roles, functions and activities required by society to ensure the health of each citizen [1,2]. GPP, unlike other good practices, which together guarantee the quality of medicines at all stages of the life cycle, has a special feature - in terms of GPP are not only professional questions related to the circulation of drugs and other products in the pharmacy range, but also the relationship between the pharmacy specialist and the patient, aimed at providing optimal medical care based on evidencebased medicine for the well-being and commonweal of the population.

The importance questions of GPP development for the practical implementation of pharmacies and abidance specialisti with GPP requirements were considered in their scientific publications: Nemchenko A.S. [3]; Ubohov S.H., Trokhymchuk V.V., Zahorii H.V. [4]; Zupanets I.A., Piminov O.F., Zaichenko H.V. [5]; Lytvynenko T.M., Soloviova V.P. [6] and others. In the works studied the questions of GPP implementation in Ukraine as part of a complex of good practice, the current state of the practical application of certain elements of GPP, in particular, the implementation of protocols as pharmacist, the need for students to master the basics of GPP in the educational process of high school and so on.

At the same time, there is no scientific work, which would be studied approaches to GPP implementation in practice of pharmacies in Ukraine in the form of a process model that determines the relevance social and practical value of work.

Purpose of the study - development of a process model of GPP implementation in the activity of pharmacies in Ukraine and reasoning of its components.

Material and methods. The materials of the study were of the FIP/WHO guidelines for GPP, the normative acts of Ukraine, scientific publications on the development and implementation of GPP in Ukraine and abroad. Methods of comparative analytical, logical, systematic analysis and generalization of information material were used in the study.

Research results. The logical continuation of the strategy of implementation in Ukraine of the system of good practices at all stages - from production to application of medicines was the question of implementation of GPP requirements into Ukrainian legislation. Adequate project order of the Ministry of Health (MOH) of Ukraine "On approval of the Guideline "Medicines. Good Pharmacy Practice" was submitted for public discussion and published on the official website of the MOH of Ukraine in January 2013 [7]. A few months later, in accordance with the order of the MOH of Ukraine on May 30, 2013, № 455, the FIP/WHO guidelines for GPP was selected as the basic information source for the development of national GPP standards. The Department of Quality Control of Medical Services as a division of the MOH of Ukraine and the State Enterprise "State Expert Center of the $\mathrm{MOH}$ of Ukraine" was entrusted to provide methodological support for this guideline [1]. However, the question under consideration has not been further developed.

In the $21^{\text {st }}$ millennium, the mission of pharmacy practice is to promote public health and provide effective pharmaceutical assistance to patients by optimizing the use of drugs on evidencebased medicine. In the 21 st millennium, the mission of pharmacy practice is to promote public health and provide effective pharmaceutical care to patients by optimizing the use of drugs on evidencebased medicine. Satisfying these needs of society is possible through the implementation of a number of pharmaceutical staff roles the FIP/WHO guidelines for GPP, including:

- prepare, obtain, store, secure, distribute, administer, dispense and dispose of medical products;

- provide effective medication therapy management;

- maintain and improve professional performance;

- contribute to improve effectiveness of the health-care system and public health.

However, if we consider GPP as a whole, the components that will ensure the proper functioning of pharmacies are the following: Guidance of Good Pharmacy Practice, National Standards of GPP and standard operating procedures (SOPs). These components in general form the process model of GPP implementation in practical pharmacy, which we developed on the example of Ukraine and presented in the figure 1. Consider each component and its place in the structure of GPP.

Proposed Guidance of Good Pharmacy Practice (then - Guidance of GPP), which developed on conditions of cooperation of public and professional scientific and educational organizations in Ukraine, focused on content and functional-role approach to the development of national standards of pharmacy practice [8]. This document includes eight separate guidelines of the processes, which inherent pharmacy in the pharmaceutical activity for retail sales of medicines and medical devices to the population as well as extemporal manufacturing dosage forms. To the processes of quality 
management system of a typical pharmacy should include the processes of basic activities (product purchasing, entering quality control, realization, storage, actions in case of recall of poor quality products), providing processes (human resources, good condition of infrastructure, workflow), management processes (planning, conducting internal audits, analysis of the quality management system by leadership, etc.). These process guidelines should have the status of national standards.

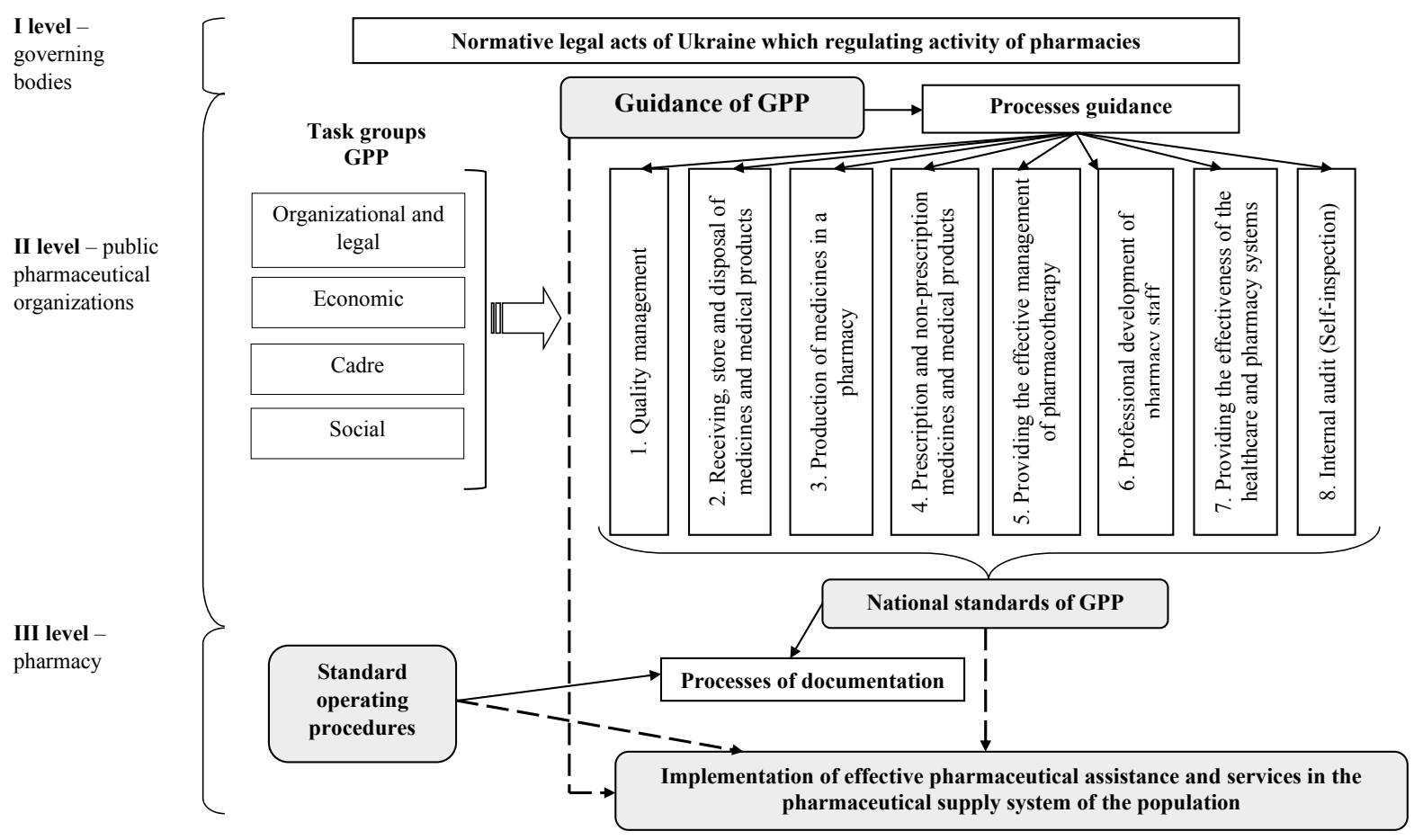

Fig. 1. The recommended process models of Good Pharmacy Practice in Ukraine

Guidance of GPP aimed at forming effective quality management system to provide pharmacies population quality, effective and safe medicines and pharmaceutical products range that have the right to buy and sell pharmacies and their structural units in accordance with applicable law [1]. The proposed Guidance of GPP may form the basis for the adoption of the GPP Guidelines at the national level [8].

The Guidance of GPP includes the introduction, terms and definitions, notations and abbreviations and 8 process guidelines, each with regulatory references to current Ukrainian legislation, and also contains requirements for basic processes that correspond to the functional and role-based approach to pharmacy professionals, documentation that ensures the processes of registration and control in the quality management system, bibliography.

Also, the Guidance of GPP establish the procedure for developing a standard SOP for effective use in practice, taking into account the specificities of each particular pharmacy. This document contains the general information, structure and content of the SOP, the procedure for the development and storage of the SOP, the procedure for making changes to the SOP, requirements for the design of the SOP, a list of sources of information, a letter-acquaintance with the content of the SOP. To improve the work of pharmacies proposed SOP typical structure of the semantic content and the list of standard SOPs for functionally-role approach [8].

As noted above, the GPP rules, in addition to retail sales of medicines and medical devices, declare a significant extension of the duties of pharmacy professionals and strengthen their responsibility in providing pharmaceutical care and services, reliable and objective information about the use of medicines, provide the concept of responsible self-medication, strengthening public health, disease prevention, etc. In addition, attention is accent to the continuous professional development of pharmacy specialists as a strategy to improve their current and future activities.

Development and implementation in practice of pharmacies of national GPP standards by functional and role-based approach will increase the priority of the social function of the pharmacy and image of the pharmaceutical worker in society, which will increase the efficiency of the system of pharmaceutical providing to the population. For the proper implementation of pharmacy by these roles need to set minimum standards for GPP, in determining the amount which at the national level should take 
into account the importance of each of the roles pharmacist for individual patients and society as a whole, the existing resource provision and the corresponding competence of specialists to carry out its functions.

To implement GPP common purpose, namely to ensure the quality of pharmacy services in the pharmaceutical system providing the population, attached to development of national standards expedient to form separate groups of tasks to achieve, and further - to monitor implementation of GPP results at the macroeconomic or microeconomic levels. The FIP/WHO guidelines for GPP declare the establishment of legal, staffing and economic task forces, each of which plays a role in providing pharmaceutical assistance and services are properly maintained [2].

These complex task groups will provide a solution to social problems as one of the main functions of the pharmacy. In recent years, the range of services provided by a pharmacist has expanded in the direction of the pharmacy practice in the new millennium, in particular, the social orientation of activities for concrete patient and society as a whole. In addition to providing manufacturing, trading and information functions, a specialist of a pharmacy must provide effective pharmaceutical services (pharmaceutical care, informing the population about the due management of pharmaceutical waste in accordance with the principles of "green pharmacy", providing free and preferential drugs, participation in government programs such as "Available Medicine", etc.).

The conducted content analysis of the current regulatory documents which regulating pharmaceutical activity in Ukraine, with the aim of establishing the existing ways of realization of the tasks of pharmacy practice defined by us, revealed that most elements of GPP standards are already presented in our legislation, but in the absence of mechanisms for their implementation in practice. For example, regulatory legal acts on organizational and legal tasks put forward requirements for staff, quality control of drugs and pharmacy practices in general. In terms of staff providing it should be noted that the requirements for qualification and level of competence of specialists are formed. However, the unresolved questions of quantitative indicators of human resources for correct implementation of the rules GPP pharmacy, calculating the required number of pharmacies, the distance between them, the valuation of labor experts, etc. [1,9].

In general, we are considered by the national standard for GPP to be an interconnected set of task groups that aim to provide the individual roles and functions of pharmacy professionals. In our opinion, the national standard for GPP should be consolidated to the nationwide scope document that will ensure at the pharmacy level the implementation of the requirements of the National Medicinal Policy, will allow to eliminate the contradictions in regulatory legal acts by different branches of government, as well as to implement the requirements of the world standards in providing pharmaceutical assistance and services.

Based on the requirements of the FIP/WHO guidelines for GPP, other WHO/FIP guidance (for example, "Developing Pharmacy Practice: A Focus on Patient Care", 2006), previously researched approaches to the formation components of standards for GPP in European Union countries, features of domestic pharmacy practice, of the range of services of pharmacy in the system of pharmaceutical supply to the population, we have proposed the draft structure of the national standard for GPP, which meets the generally accepted $\mathrm{n}$ regulatory legal document, as well as the requirements for details (name of standard, subject of regulation, date of adoption) and structure (introductory part, sections, annexes) $[2,9,10]$. Thus, our proposed national standard pharmacy practice includes the following sections:

$\checkmark$ The name of the standard, date of development or revision (gives an idea of the content of the document, determines its relevance);

$\checkmark$ Conditional abbreviations (to make the information provided available);

$\checkmark$ Introduction (essence of the standard and justification of the need for development);

$\checkmark$ Terms and definitions (identification of terms for which definitions are required);

$\checkmark$ Scope (area), application (defining the scope and limits of use);

$\checkmark$ Requirements for pharmaceutical activities (requirements for certain types of pharmaceutical activities and indicators for assessing compliance with the provision of pharmaceutical assistance and services to the approved requirements);

$\checkmark$ Annexes (information required to complete the coverage of material that cannot be placed in the main part of the standard because of the large amount, as well as instructions, methods, descriptions of algorithms, computer programs);

$\checkmark$ Bibliographic resources (information about documents used in the development of this standard, references to additional sources of literature and other resources);

$\checkmark$ Notes (optional secondary information is relevant, if need it) [9]. 
To assess the effectiveness of implementation requirements in accordance with the type of tasks GPP (organizational, legal, economic, personnel, social) different types of indicators are developed, which form the set (family) of indicators. These indicators are broken down into quantitative (quantitative detailed assessment of production processes) and substantive (qualitative monosemantic assessment - presence or absence, implementation of certain obligations). These indicators are used to assess the effectiveness of the performance of the main tasks of the pharmacy for each area of tasks, which are outlined in the national standard of pharmacy practice. We offer the following types of indicators:

- structural (number and sufficiency of pharmaceutical staff; availability of educational materials in the pharmacy; average number of sold drugs per patient);

- process (availability of staff skills in communication with visitors; ability to carry out pharmaceutical care; level of training of specialists; information content of the pharmacy website);

- intermediate achievements (number of educational activities conducted; number of medicines released under the "Available Medicine" program);

- effective (the presence in patients' knowledge about responsible self-medication, their satisfaction of the level consultations, the number of prescriptions dispensed under the "Available Medicine" program).

In our opinion, the development of GPP information support and practical implementation should begin with the adoption of public pharmaceutical organizations the Guidance of GPP as a document declaring general requirements for the basic processes of pharmacy integrated into separate process guides. In the future, it is advisable for each process or its main components to develop national standards of GPP, which, by through of their structure, will be informative for professionals in carrying out self-assessment of the level of competence, for pharmaceutical business owners and managers - in carrying out internal audits, for public authorities - in carrying out scheduled and unscheduled inspections of business entities.

In order to ensure that pharmacists carry out their day-to-day responsibilities properly, pharmacy management needs to develop a SOPs based on the typical structure of SOP, taking into account the procedure for its development, approval and circulation, as presented in the Guidance of GPP [8]. In fact, each SOP will provide specialist with answers to 3 questions: 1) who? (participates in the realization, carry out its requirements) and what? (what resources are needed for its implementation); 2) where? (in which the unit must comply SOP); 3) when? (in the period of time necessary to keep fit, carry out the requirements of SOPs, and in what sequence).

Conclusions. As follows, based on the materials, the process model of GPP implementation in pharmacy of Ukraine was proposed and the expediency of developing its components, namely the Guidance of GPP, national standards of GPP and SOPs.

\section{REFERENCES}

1. Zakonodavstvo Ukrainy. URL: https://zakon.rada.gov.ua.

2. Forty-fifth report of the WHO Expert Committee on specifications for pharmaceutical preparations (WHO technical report series; no. 961), 2011: 310-323. URL: https://apps.who.int/iris/bitstream/handle/10665/44079/WHO_TRS_961_eng.pdf

3. Podpruzhnykov Yu. V., Nemchenko A. S., Andriukova L. N., Humeniuk N. Y. Sistema kachestva i nadlezhaschie praktiki $\mathrm{v}$ farmatsii [Quality system and good practices in pharmacy]. Kyiv: TOV "SIK HRUP UKRAINA", 2017: 619-651.

4. Ubohov S. H., Trokhymchuk V. V., Zahorii H. V., Fedorova L. O. Doslidzhennia stanu hotovnosti aptechnykh zakladiv Ukrainy do vprovadzhennia intehrovanykh system yakosti. Farmatsevtychnyi zhurnal. 2019; 2: 3-11. doi: 10.32352/0367-3057.2.19.01

5. Zupanets I. A., Piminov O. F., Zaichenko H. V. et al. Nalezhna farmatsevtychna praktyka: implementatsiia protokoliv provizora/farmatsevta u pisliadyplomnu osvitu spetsialistiv farmatsii. Klinichna farmatsiia. 2015; 4: 4-8.

6. Lytvynenko T. M., Soloviova V. P., Puchkan L. O. Nalezhna aptechna praktyka: vse pochynaietsia z yakisnoi pidhotovky farmatsevtychnoho fakhivtsia. Aktualni pytannia farmatsevtychnoi i medychnoi nauky ta praktyky. 2013; 2(12): 67-69.

7. Proekt nakazu MOZ Ukrainy "Pro zatverdzhennia Nastanovy "Likarski zasoby. Nalezhna aptechna praktyka". Ezhenedelnyk Apteka. 2013; 874(3): 19-20.

8. Hala L. O., Nemchenko A. S., Pasichnyk M. F. Rekomendovana struktura ta zmist "Kerivnytstva z Nalezhnoi aptechnoi praktyky" v Ukraini: metod. rek. K., 2019: 45.

9. Hala L. O., Panfilova H. L. Naukovo-prykladni pidkhody do rozrobky struktury y zmistu natsionalnoho standartu Nalezhnoi aptechnoi praktyky: metod. rek. K., 2019: 22.

10. Developing pharmacy practice: A focus on patient care. 2006.87 p. URL: https://www.fip.org/files/fip/publications/DevelopingPharmacyPractice/DevelopingPharmacyPracticeEN.pdf 